\title{
Micropropagation of Crambe Abyssinica Hochst. Ex R.E. Fr.
}

\section{Elias Terra Werner ${ }^{1 *}$, Andreia Barcelos Passos Lima Gontijo ${ }^{2}$, José Augusto Teixeira do Amaral ${ }^{3}$, Jaquelini Luber ${ }^{4}$, Edilson Romais Schmildt ${ }^{2}$}

${ }^{1}$ Departamento de Biologia, Centro de Ciências Exatas, Naturais e da Saúde, Universidade Federal do Espírito Santo, Alto Universitário, s/n, Caixa Postal 16, Alegre - ES - Brasil

${ }^{2}$ Departamento de Ciências Agrárias e Biológicas, Centro Universitário Norte do Espírito Santo, Universidade Federal do Espírito Santo, São Mateus - ES - Brasil

${ }^{3}$ Departamento de Produção Vegetal, Centro de Ciências Agrárias e Engenharias, Universidade Federal do

Espírito Santo, Alegre - ES - Brasil

${ }^{4}$ Programa de Pós-Graduação em Biodiversidade Tropical, Centro Universitário Norte do Espírito Santo, Universidade Federal do Espírito Santo, São Mateus - ES - Brasil

\section{*Corresponding author: elias.werner@ufes.br}

\begin{abstract}
Crambe abyssinica Hochst. Ex. R. E. Fr. is an oilseed species that produces non-edible oil, initially employed in Brazil as a culture for soil surface coverage and animal feed. However, with stimulation of the production and use of renewable energies, it arose as an interesting alternative for biodiesel production. The aim of this work was to describe a protocol for micropropagation of crambe, using apical segments as explants. Crambe seeds germinated in vitro in medium MS $1 / 2$ provided apical segments adequate to the micropropagation process. In the shoot induction phase, testing the interaction of the cytokinins 6-benzylaminopurine (BAP), kinetin (KIN) and thidiazuron (TDZ) as well as different concentrations thereof, the highest numbers of shoots per explant were obtained with $5 \mu \mathrm{M} \mathrm{BAP}$ at 30 days (9.26 shoots) and $15 \mu \mathrm{M}$ BAP at 60 days (18.08 shoots) of in vitro culture. In the elongation with $1 \mu \mathrm{M}$ gibberellic acid $\left(\mathrm{GA}_{3}\right)$, the mean length of the shoots turned from $3.61 \mathrm{~cm}$ to $5.03 \mathrm{~cm}$ after 30 days. The highest percentage of rooting was of $30 \%$ with $0.25 \mu \mathrm{M}$ naphthalene-acetic acid (NAA). The results of this work revealed a satisfactory frequency of shoot regeneration from apical segments of crambe in media containing $5 \mu \mathrm{M}$ BAP, and adequate elongation with $1 \mu \mathrm{M}$ GA . Nevertheless, there is still need for efficient rooting and acclimatization for complete in vitro propagation of crambe.
\end{abstract}

Keywords: cytokinins; in vitro; oilseeds; organogenesis; regeneration.

\section{Introduction}

Crambe abyssinica Hochst. Ex. R. E. Fr. (Brassicaceae) is an oilseed species that produce non-edible oils for biodiesel production. Originated in Ethiopia and domesticated in the Mediterranean region (Knights, 2002), this species was introduced in Brazil in the state of Mato Grosso do Sul (Dahlke and Simonetti, 2010). It was initially employed as a culture for soil surface coverage and animal feed (30 to $32 \%$ of crude protein) (Neves et al., 2007), but with the stimulation of the production and use of renewable energies, crambe arose as an interesting alternative also for biodiesel production (Roscoe et al., 2007).

Other advantages of the cultivation of crambe refers to its rapid cycle (Chhikara et al., 2012), high biomass production (Zulfiqar et al., 2011), elevated amount of seeds (Falasca et al., 2010), low production cost in relation to other oilseeds (Jasper et al., 2010), resistance to insects (Kmec et al., 1998), percentage of total oil in the seed (32 to $38 \%$ ), which surpasses that of soybean (Falasca et al., 2010), and elevated percentage of erucic acid in the oil extracted from the seeds (50-60\%), useful in the plastic and lubricant industry (LaraFiorezea et al., 2013). Moreover, the culture has potential for phytoremediation against heavy metals (Paul et al., 2010).
There is great interest in the breeding of cultivated species with the aim of increasing productivity. For this, genetic transformation and in vitro culture techniques are important tools to be employed. However, the genetic transformation of plants demands the successful application of these techniques, requiring an efficient, viable, genetically loyal propagation system that provides plant material of good quality to satisfy this demand (Memon et al., 2009).

According to $\mathrm{Li}$ et al. (2011), the development of an efficient protocol for the regeneration of crambe cultured in vitro, by means of tissue culture techniques, becomes relevant to improve the quality and production of oil in the species.

With regards to the micropropagation, different parts of the plant have been used as explant, for instance hypocotyls ( $\mathrm{Li}$ et al., 2010, 2011; Palmer and Keller, 2011; Chhikara et al., 2012), cotyledons (Palmer and Keller, 2011; Chhikara et al., 2012), root (Palmer and Keller, 2011; Chhikara et al., 2012) and cells in culture (protoplasts) (Gao et al., 1998), with only the protocol developed by $\mathrm{Li}$ et al. (2011) obtaining a satisfactory rate of shoot regeneration, of $95 \%$. Although a great number of genetically identical plants can be regenerated by means of micropropagation, some somaclonal variations can be detected (Miguel and Marum, 2011; Pathak 
and Dhawan, 2012), which in turn depend on various factors, among which the type of explant used should be considered (Leela et al., 2011). Cultivation in vitro from explants with meristematic regions, such as apical and nodal segments, are very popular and important (Zoghlami et al., 2012), as the frequency of somaclonal variations in the regenerated plants is low (Singh et al., 2012). Along these lines, the aim of the present work was to describe a protocol for micropropagation of crambe using apical segments as explants.

\section{Results and discussion}

\section{Shoot multiplication}

The seeds of crambe germinated in vitro developed healthy plants (Fig 1A) suitable as sources of apical segments to be used as explants (Fig 1B), and these were established and developed adequately in vitro (Fig 1-C-E). In general, the results evidence that the used cytokinins efficiently and satisfactorily promoted the multiplication of shoots from apical segments of crambe. The medium MS without cytokinins $(0 \mu \mathrm{M})$ produced numerous roots at 30 days and the apical dominance was not affected, but at 60 days senescence and death of most of the plantlets was noticed (data not shown). The same results were reported for apical segments of Raphanus sativus var. radicula Pers. (Pavlović et al., 2012). This demonstrates the importance of cytokinins in the suppression of apical dominance, resulting in ample development of new shoots and inhibition of root appearance. In the phase of shoot induction, the analysis of variance indicated that there was significant interaction between the cytokinins (BAP, KIN and TDZ) and the concentrations (0, 5, $10,15$ and $20 \mu \mathrm{M})$ only for the variables number of shoots per explant (NSE) at 60 days. This suggests the existence of differentiated response in the multiplication of shoots in relation to the dosages of each cytokinin after a longer period of contact with the explant (Table 1).

For NSE, at 30 days, the analysis of variance showed that only the types of cytokinin were significant (Table 1), and that among the tested cytokinins, BAP obtained the highest value (9.26 shoots), although not differing significantly from TDZ (8.23 shoots) (Table 2). At 60 days, the significant interaction between the factors demonstrated that, in all tested concentrations, BAP presented values superior to the other compounds with a significant difference, being that at the concentration of $15 \mu \mathrm{M}$ the highest value for NSE (18.08 shoots) was detected (Table 3 ). In both evaluation times, TDZ was more efficient than KIN in inducing shoots in most of the concentrations, differing statistically only at 60 days with $5 \mu \mathrm{M}$ (Tables 2 and 3). It is important to notice that there was considerable increment in NSE from 30 days (general mean: 8.69) to 60 days (general mean: 12.98), indicating that until this time point the cytokinins acted in a regular way.

The analysis of regression for the cytokinin concentrations by NSE at 30 and 60 days is presented in figure 2 . It can be verified that the response was quadratic, except for KIN at 60 days, which was positive linear. By the regression equation of $\mathrm{BAP}$, at 30 days, with a concentration of $12.23 \mu \mathrm{M}$ it would be possible to obtain a maximum value of 10.62 shoots, and at 60 days and $13.46 \mu \mathrm{M}$, this number might reach 18.74 shoots.

BAP is one of the cytokinins with lowest cost, and has been very efficacious in the multiplication of diverse Brassicaceae species (Shukla and Sawhney, 1991; Memon et al., 2009; Ishigaki et al., 2009). Studies related to induction of shoots and regeneration of whole plants from apical segments have not yet been described for crambe. However, previously published protocols for in vitro regeneration were obtained by using hypocotyls as explants, enabling studies related to the genetic breeding of the species, such as transgenesis and somatic hybridization (Wang and Luo, 1998; Wang et al., 2003, 2004).

Li et al. (2010), working with hypocotyls as explants, described a protocol for direct induction of shoots in medium MS supplemented with $10 \mu \mathrm{M}$ TDZ and $2.7 \mu \mathrm{M}$ NAA, promoting a regeneration frequency of up to $60 \%$ for $C$. abyssinica cv. Galactica. In a new work, Li et al. (2011) obtained $95 \%$ of shoot regeneration using the medium Lepiovre, also supplemented with $10 \mu \mathrm{M}$ TDZ and $2.7 \mu \mathrm{M}$ NAA. Chhikara et al. (2012) noted efficient regeneration in medium MS with $8.8 \mu \mathrm{M}$ BAP and $0.10 \mu \mathrm{M}$ NAA, with a frequency of $70 \%$, starting from calli of hypocotyl. In this work, although a different explant was used than in the above-cited works, the applied concentrations of cytokinin were close, and efficiently promoted the expected morphogenetic response both with BAP as well as with TDZ. All the results above corroborate the fact that, just as for the Brassicaceae species, also for crambe the value of 5.0 to 10 $\mu \mathrm{M}$ BAP is ideal for in vitro regeneration of shoots, and that this regulator at these concentrations has been one of the most used for this family.

\section{Shoots elongation}

The shoots of crambe that presented better morphological aspect and development in the phase of shoot induction, regenerated from the treatments with BAP and TDZ, besides the control, were selected for the elongation phase. All shoots obtained through these treatments were transferred into medium MS supplemented with a single concentration (1 $\mu \mathrm{M})$ of $\mathrm{GA}_{3}$, and were kept under these conditions for 30 days. The analysis of variance in this phase demonstrated that there was no significant interaction between the cytokinins and the concentrations for the MLS (Table 4). This indicates that the influence of $\mathrm{GA}_{3}$ on shoot elongation was independent from the cytokinins and concentrations previously applied in the phase of shoot induction. Besides, this response on the elongation can be verified when comparing the previous general mean value, which was of $3.61 \mathrm{~cm}$ at 60 days; after 30 days with presence of $\mathrm{GA}_{3}$ in the medium, an overall MLS of $5.03 \mathrm{~cm}$ was obtained (Table 4). The $\mathrm{GA}_{3}$ added to the culture medium may promote increase in shoot length due to stimulation of cell division and elongation (Rocha et al., 2009). The incorporation of $1 \mu \mathrm{GA}_{3}$ produced shoots with overall mean length considered adequate to perform the following steps of the micropropagation, which are the rooting and subsequent acclimatization of the plants. Shoots with small length may show low percentage of rooting if cultivated directly in rooting media, or originate saplings with low quality for the acclimatization phase (Rocha et al., 2009).

Purkayastha et al. (2010) reported that $0.5 \mu \mathrm{M} \mathrm{GA}_{3}$ increased threefold the elongation in $98 \%$ of the cultures. The elongation of atrophied shoots, generated in medium containing cytokinins for elevated times and concentrations, is dependent on the reduction or absence of the cytokinins or incorporation of $\mathrm{GA}_{3}$ to the medium (Paul et al., 2010). This effect of $\mathrm{GA}_{3}$ in relation to BAP has also been reported in other plant species (Sugla et al., 2007; Purkayastha et al., 2008). Chhikara et al. (2012) mentioned that, to induce the development of adventitious roots in crambe in vitro, it is necessary to incorporate $\mathrm{GA}_{3}$ into the medium. 
Table 1. Summary of the analysis of variance for the number of shoots per explant (NSE) and percentage of survival (\% Surv.) of $C$. abyssinica plantlets under interaction of different concentrations of BAP, KIN and TDZ after 30 and 60 days of culture in vitro in MS medium.

\begin{tabular}{llllll}
\hline \multirow{2}{*}{ FV } & DF & \multicolumn{2}{l}{ F-Test } & & \%Surv. \\
\cline { 3 - 6 } & & NSE & & \\
& $30 \mathrm{~d}$ & $60 \mathrm{~d}$ & $30 \mathrm{~d}$ & $60 \mathrm{~d}$ \\
\hline Cytokinin (A) & 2 & $5.05^{* *}$ & $56.42^{* *}$ & $0.71^{\text {ns }}$ & $1.50^{\text {ns }}$ \\
Concentration (B) & 4 & $18.79^{--}$ & $32.15^{--}$ & $1.52^{--}$ & $30.71^{--}$ \\
Int. A x B & 8 & $1.20^{\text {ns }}$ & $6.46^{* *}$ & $0.37^{\text {ns }}$ & $1.10^{\text {ns }}$ \\
Residue & 60 & - & - & - & - \\
\hline General mean & - & 8.69 & 12.98 & 96.95 & 91.72 \\
\hline CV $(\%)$ & - & 13.41 & 12.11 & 6.58 & 6.46 \\
\hline
\end{tabular}

**, * significant at 0.01 and 0.05 probability, respectively; ns: non-significant; $\mathrm{CV}(\%)$ : coefficient of variation in percentage.

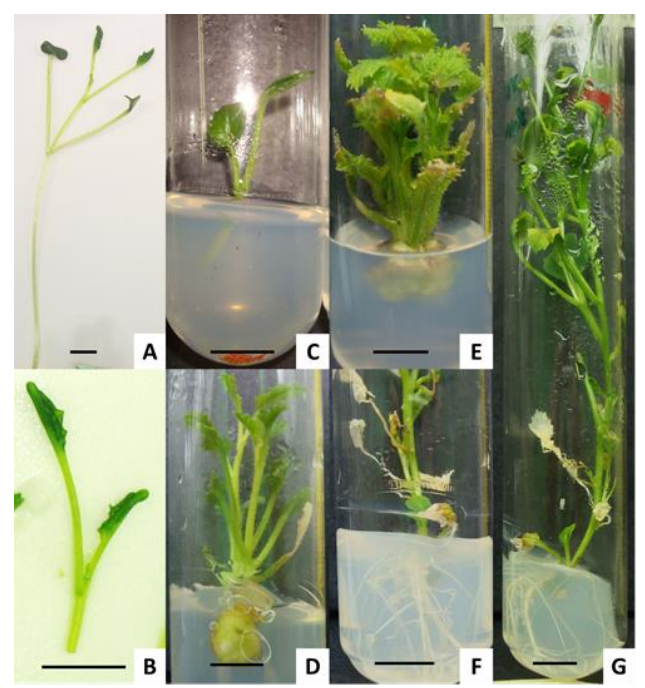

Fig 1. Regeneration of $C$. abyssinica through apical segments in MS medium. (A) Plant germinated in vitro; (B and C) Apical segment used as explant (0 days); (D and E) Shoots induced with 5.0 $\mu \mathrm{M}$ BAP at 30 and 60 days, respectively; (F and G) Rooting of shoots with $0.5 \mu \mathrm{M}$ NAA at 120 days. $\mathrm{Bar}=1.0 \mathrm{~cm}$.

Table 2. Mean number of shoots per explant (NSE) of C. abyssinica plantlets under different cytokinins after 30 days of culture in vitro in MS medium.

\begin{tabular}{ll}
\hline Cytokinins & Mean \\
\hline BAP & $9.26 \mathrm{a}$ \\
KIN & $8.23 \mathrm{~b}$ \\
TDZ & $8.58 \mathrm{ab}$ \\
\hline
\end{tabular}

There is no difference between means followed by the same letter by Tukey test at $5 \%$.
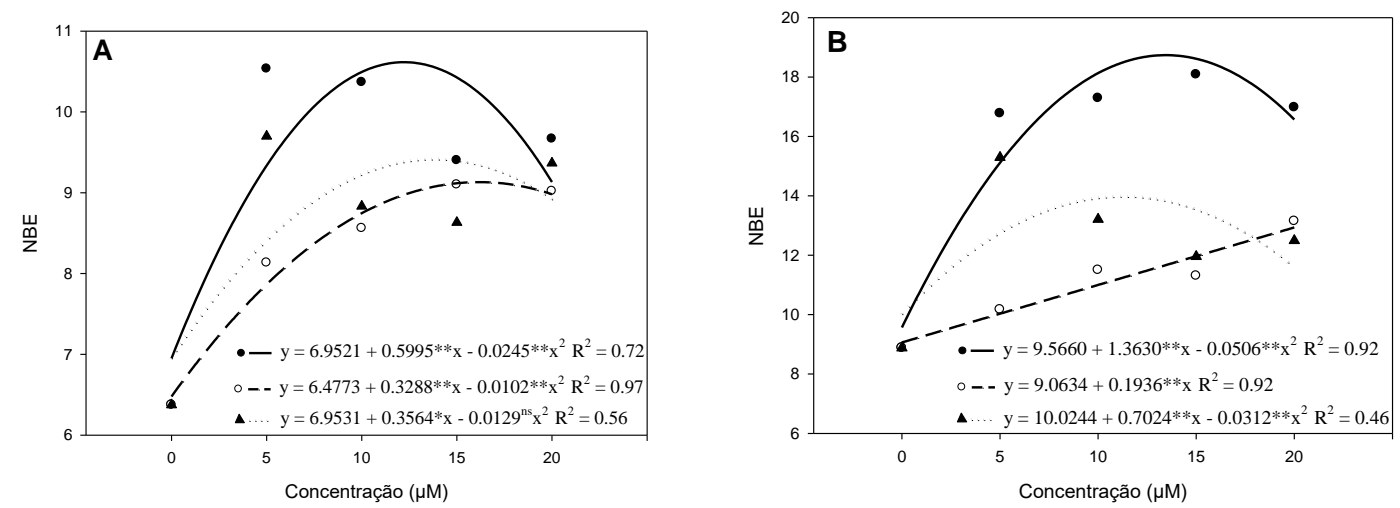

Fig 2. Polynomial regression of the mean values for the number of shoots per explant (NSE) of $C$. abyssinica plantlets subjected to

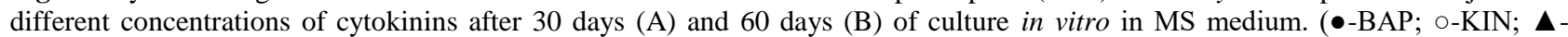
TDZ). 
Table 3. Mean number of shoots per explant (NSE) of $C$. abyssinica plantlets under interaction of different cytokinins and concentrations after 60 days of culture in vitro in MS medium.

\begin{tabular}{llllll}
\hline \multirow{2}{*}{ Cytokinins } & \multicolumn{5}{c}{ Concentration $(\mu \mathrm{M})$} \\
\cline { 2 - 6 } & 0 & 5 & 10 & 15 & 20 \\
\hline BAP & $8.87 \mathrm{a}$ & $16.77 \mathrm{a}$ & $17.28 \mathrm{a}$ & $18.08 \mathrm{a}$ & $16.97 \mathrm{a}$ \\
KIN & $8.87 \mathrm{a}$ & $10.16 \mathrm{~b}$ & $11.50 \mathrm{~b}$ & $11.30 \mathrm{~b}$ & $13.14 \mathrm{~b}$ \\
TDZ & $8.87 \mathrm{a}$ & $15.29 \mathrm{a}$ & $13.21 \mathrm{~b}$ & $11.95 \mathrm{~b}$ & $12.49 \mathrm{~b}$ \\
\hline
\end{tabular}

There is no difference between means followed by the same letter in the column by Tukey test at $5 \%$.

Table 4. Summary of the analysis of variance for mean length of shoots (MLS) (cm) and survival percentage (\%Surv.) in $C$. abyssinica plantlets derived from treatments with BAP and TDZ, subjected to elongation with $1 \mu \mathrm{M}$ GA3 at 90 days of culture in vitro in MS medium.

\begin{tabular}{|c|c|c|c|}
\hline \multirow{2}{*}{$\mathrm{FV}$} & \multirow{2}{*}{$\mathrm{DF}$} & \multicolumn{2}{|c|}{ F-Test } \\
\hline & & MLS & \%Surv. \\
\hline Cytokinin (A) & 1 & $1.23^{\mathrm{ns}}$ & $0.18^{\text {ns }}$ \\
\hline Concentration (B) & 4 & $8.81^{--}$ & $5.02^{--}$ \\
\hline Int. A x B & 4 & $0.37^{\mathrm{ns}}$ & $1.80^{\mathrm{ns}}$ \\
\hline Residue & 40 & - & - \\
\hline General mean & - & 5.03 & 90.68 \\
\hline $\mathrm{CV}(\%)$ & - & 12.67 & 6.90 \\
\hline
\end{tabular}

Table 5. Summary of the analysis of variation for percentage of rooting (\%Root.) and of survival (\%Surv.) in $C$. abyssinica plantlets derived from treatments with BAP and TDZ at $5 \mu \mathrm{M}$, subjected to rooting with NAA and IAA at the concentrations of $0.0,0.25$ and $0.50 \mu \mathrm{M}$, at 120 days of culture in vitro in MS medium.

\begin{tabular}{|c|c|c|c|}
\hline \multirow{2}{*}{ FV } & \multirow{2}{*}{ DF } & \multicolumn{2}{|l|}{ F-Test } \\
\hline & & \%Root. & \%Surv. \\
\hline Cytokinin (A) & 1 & $7.53^{* *}$ & $0.94^{\mathrm{ns}}$ \\
\hline $\operatorname{Auxin}(\mathrm{B})$ & 4 & $1.76^{\mathrm{ns}}$ & $1.04^{\mathrm{ns}}$ \\
\hline Int. A x B & 4 & $1.17^{\mathrm{ns}}$ & $1.60^{\mathrm{ns}}$ \\
\hline Residue & 40 & - & - \\
\hline General mean & - & 13.66 & 88.00 \\
\hline CV (\%) & - & 15.86 & 22.09 \\
\hline
\end{tabular}

\section{Root induction}

According to Purkayastha et al. (2010), the prolonged cultivation in medium containing this regulator yields thin and excessively elongated plants, inadequate for rooting. This may also explain the low percentage of rooting obtained in the present work. The elongated shoots arising from the treatments with $5 \mu \mathrm{M}$ BAP and $5 \mu \mathrm{M}$ TDZ were transferred into root induction media with NAA and IAA. After 30 days in these conditions, the shoots responded to this stimulus (Fig $1-\mathrm{F}$ and $\mathrm{G})$. Nonetheless, there was low yield in these treatments, with an overall mean of $13.66 \%$ of rooting. The analysis of variation for the interaction between the concentrations of NAA and IAA (Table 5) did not demonstrate significance for \% Root. Numerically, the highest percentage of rooting was of $30 \%$, detected in the treatment with $0.25 \mu \mathrm{M}$ NAA in plantlets originated from 5 $\mu \mathrm{M}$ BAP (data not shown). The results of the analysis of variance indicated difference only in the tested cytokinins, in which plantlets obtained from $5 \mu \mathrm{M}$ BAP presented general mean value higher than $20.66 \%$ of rooting, compared to $6.66 \%$ when subjected to $5 \mu \mathrm{M}$ TDZ.

The phenomena involved in rooting are difficult to identify, owing to their complexity, thus constituting an obstacle for adequate knowledge of this stage (Assis and Teixeira, 1998). The low rooting found for crambe may be related to the residual effects of the cytokinins and gibberellin inserted in the previous phases. According to Grattapaglia and Machado (1998), the addition of gibberellins to the medium is unnecessary and may be harmful to rooting, whereas cytokinins added to the medium may cause its inhibition (Grimaldi et al., 2008). It was verified that explants of species with rooting difficulty have a high concentration of endogenous cytokinin, whereas species with facility to root have low concentrations of it (Hartmann et al., 1990).

The capacity of producing roots and shoots depends on the proportion cytokinin/auxin in the culture medium (Shukla and Sawhney, 1991). A higher value of this relationship favors the formation of shoots, while a lower value favors the formation of roots (Skoog and Miller, 1957; Taiz and Zeiger, 2006; Rout et al., 2006); besides, residual effects should be taken into account. The great difficulty hereby lies in measuring the residues of growth regulators during the micropropagation phases. According to Flores et al. (2009), an alternative to minimize this problem is the transfer of shoots into a nourishing medium free of growth regulators. With regards to the higher inhibitory effect reported for TDZ in the regeneration of crambe roots, it has also been described for other species (Khawar et al., 2004; Flores et al., 2007). This is explained by the fact that TDZ alters the metabolism of natural cytokinins, culminating in increase in the endogenous content of cytokinins (Mok et al., 1987, apud Flores et al., 2009).

Some works report rooting of crambe shoots from hypocotyls used as explants. $\mathrm{Li}$ et al. (2010) reached 59 to $67 \%$ of rooting with 0.54 and $0.27 \mu \mathrm{M}$ NAA, respectively, in shoots from treatment with $10 \mu \mathrm{M} \mathrm{TDZ}$ and $2.7 \mu \mathrm{M}$ NAA. These authors also relate that $0.49 \mu \mathrm{M}$ and $0.25 \mu \mathrm{M}$ IBA caused low frequencies of rooting, of 24 and $18 \%$, respectively. In turn, Chhikara et al. (2012) induced roots 
using $9.5 \mu \mathrm{M}$ IBA in shoots obtained with $8.88 \mu \mathrm{M}$ BAP and $0.10 \mu \mathrm{M}$ NAA, but did not reveal the efficiency of this treatment. Wang and Luo (1998) achieved satisfactory rooting in crambe shoots generated from immature ovary after 15 days with medium MS $1 / 2+0.28 \mu$ M IBA. Perhaps the long culture time and the residues of growth regulators were responsible for the low rooting seen in the present work. Success in the rooting of the explants is a prerequisite for any micropropagation protocol, as it is important in order to facilitate the establishment of the plant in the acclimatization process (Pati et al., 2006).

\section{Acclimatization}

In acclimatization, the survival rate during the preacclimatization process was satisfactory, but the procedure of perforating and removing the PVC film from the flasks and maintaining these conditions for 15 days was an inducing factor for the appearance of fungus in some culture media. When transferred onto the commercial substrate and soil under environmental conditions, the plantlets did not support such stress and suffered senescence, leading to death of all plantlets after 15 days. Some plants originated through the rooting in vitro, though being well rooted, including branched roots, did not survive when transplanted into ex vitro conditions (Tibola et al., 2004). Even plants with normal aspect may suffer and/or not survive this phase owing to the stress afflicted to the plants by the sudden change in relative humidity that occurs in the passage from in vitro to ex vitro conditions (Apóstolo et al., 2005). Other limiting factors in this phase occur in function of the plants under ex vitro conditions passing into an autotrophic state. This requires performance of photosynthesis to survive, as well as need to rapidly increment the absorption of salts, thus being at risk of attack by microorganisms (Kadlec et al., 2001).

In relation to crambe, few micropropagation protocols describe the acclimatization process (Li et al., 2010, 2011; Chhikara et al., 2012). However, Palmer and Keller (2011) registered $70 \%$ of survival during acclimatization, though not disclosing the adopted methodology.

Micropropagation can be affected by various factors, such as the age of the explant, nutrients, explant orientation, types and concentration of growth regulators, and also the time of culture and subculture (Shukla and Sawhney, 1991). Taking all these factors into account, the culture time and the longer period under influence of growth regulators may have affected the micropropagation process in this study.

\section{Materials and methods}

\section{Plant material}

The experiment was conducted at the Laboratory of Plant Tissue Culture of the Center for Agronomic Sciences, Federal University of Espírito Santo, ES - Brazil. Seeds of $C$. abyssinica from the cultivar FMS brilliant, harvest of 2011, obtained from the Fundação MS, located in Maracaju, Mato Grosso do Sul - Brazil, were used for the establishment of the in vitro culture.

\section{Explant source}

Apical segments were excised from crambe plantlets with 30 days age originated from germination of seeds in vitro. The seeds were initially washed in running water with neutral detergent. Under aseptic conditions in laminar flow hood, the seeds were then disinfested by immersion in antibiotic solution of penicillin $\left(10 \mathrm{mg} \mathrm{L}^{-1}\right)$ and rifampicin $\left(10 \mathrm{mg} \mathrm{L}^{-1}\right)$ for 30 minutes $(\mathrm{min}), 70 \%$ alcohol for $1 \mathrm{~min}$, followed by commercially available sodium hypochlorite $50 \%$ (active chlorine: $2-2.5 \%$ ) for $30 \mathrm{~min}$, and washed three times in autoclaved distilled water.

\section{Culture medium and culture conditions}

The culture medium used in the in vitro germination of crambe seeds was MS $1 / 2$ (Murashige and Skoog, 1962). After germination, apical segments, with approximately $2-3 \mathrm{~cm}$, were obtained and used in the micropropagation process from plantlets with 30 days age. For induction of shoots, the explants were inoculated in medium MS, testing the cytokinins 6-benzylaminopurine (BAP), kinetin (KIN) and thidiazuron (TDZ) at different concentrations $(0.0,5.0,10.0$, 15.0 and $20.0 \mu \mathrm{M})$. Subculture was carried out at 30 days, and the evaluations at 30 and 60 days after inoculation.

For elongation, the plantlets regenerated from treatments with BAP, TDZ and their concentrations were selected and transferred into medium MS with $1 \mu \mathrm{M}$ gibberellic acid $\left(\mathrm{GA}_{3}\right)$, being evaluated after 30 days (time point of 90 days). For rooting, the plantlets arising from treatments with $5 \mu \mathrm{M}$ BAP and $5 \mu \mathrm{M}$ TDZ were transferred into medium MS containing NAA (naphthalene acetic acid) or IAA (3indolacetic acid), at the concentrations of $0.0,0.25$ and 0.50 $\mu \mathrm{M}$. The evaluations were performed after 30 days in the described rooting media (time point of 120 days).

The media were supplemented with $30 \mathrm{~g} \mathrm{~L}^{-1}$ sucrose, 0.5 $\mathrm{mg} \mathrm{L}^{-1}$ silver nitrate $\left(\mathrm{AgNO}_{3}\right)$ (Li et al., 2010) and $7 \mathrm{~g} \mathrm{~L}^{-1}$ agar. After adjustment of the $\mathrm{pH}$ to 5.8 , the media were poured into test tubes of $25 \times 150 \mathrm{~mm}(10 \mathrm{~mL})$ and autoclaved under $1.1 \mathrm{~atm}$ at $121^{\circ} \mathrm{C}$, for $20 \mathrm{~min}$. All cultures were incubated in growth room with photoperiod of $16 / 8 \mathrm{~h}$ (light/dark), under fluorescent lamps providing flows of 25.2 $\mu \mathrm{mol} \mathrm{m} \mathrm{m}^{-2} \mathrm{~s}^{-1}$ photosynthetic photons, and temperature of $25 \pm 1$ ${ }^{\circ} \mathrm{C}$.

\section{Acclimatization of regenerated plants}

The plants with approximately $11 \mathrm{~cm}$ and with welldeveloped air part and root, obtained through the rooting treatments, were used for acclimatization. Still in the growth room, at intervals of seven days, the following procedures were carried out: (1) the test tube lids were substituted by film of polyvinyl chloride (PVC); (2) perforations were made in the PVC film; and (3) the film was removed completely. After this period of 21 days, the plants were removed from the tubes, the roots were washed under running water to remove excess culture medium, then transferred individually to matt plastic beakers containing commercial substrate (Vivato Slim $^{\circledR}$ ) or corrected dystrophic red-yellow latosol, both autoclaved. At this stage, the plants were nourished with solution of macro- and micronutrients in medium MS, and maintained in a place with light and room temperature.

\section{Morphological evaluations}

The phytotechnical evaluations were performed at different phases of the micropropagation, at the times of 30 and 60 days (shoot induction), 90 days (elongation) and 120 days (rooting), as to the number of shoots per explant (NSE); mean length of the shoots (MLS), using a digital pachymeter; percentage of rooting (\% Root.); and percentage of survival (\% Surv.). 


\section{Experimental design and statistical analysis}

The experiment followed a completely randomized design (CRD) and each phase (induction, elongation and rooting) was performed with five repetitions per treatment, each consisting of 10 test tubes with one explant each.

In the induction of shoots, the effect of the interaction between the cytokinins and their concentrations was determined in a $3 \times 5$ factorial scheme, having three types (BAP, KIN and TDZ) and five concentrations (0, 5, 10, 15 and $20 \mu \mathrm{M}$ ) in the factor cytokinin.

In the elongation phase with $1 \mu \mathrm{M} \mathrm{GA}$, the factorial scheme $2 \times 5$ was employed (cytokinin $\mathrm{x}$ concentrations), using plantlets obtained through treatments with BAP, TDZ and their different concentrations.

Rooting was conducted in a factorial scheme $2 \times 5$, with two cytokinins ( $5 \mu \mathrm{M}$ BAP and $5 \mu \mathrm{M}$ TDZ) and five treatments for rooting: control $(0.0 \mu \mathrm{M}), 0.25$ and $0.50 \mu \mathrm{M}$ NAA, and 0.25 and $0.50 \mu \mathrm{M}$ IAA. The data on rooting percentage $(\%$ Root.) was transformed by $[(\mathrm{x} / 100)+1]$.

The obtained data was subjected to analysis of variance, after verification of the normality and homogeneity. When significance was detected in the interactions or in the factors, the Tukey test of averages was applied on the qualitative factors, adopting $1 \%$ and $5 \%$ probability, by the software Assistat (Silva and Azevedo, 2009). For the quantitative factor (concentrations), regression analysis was effected with the software Exel (2010), with the factor being represented only with basis on the significance of the coefficients of regression and determination $\left(\mathrm{R}^{2}\right)$, with levels up to $5 \%$ probability being adopted, using the F-test, and taking into consideration the biological phenomenon in study.

\section{Conclusion}

A satisfactory frequency of shoot regeneration from apical segments of crambe occurs in media containing $5 \mu \mathrm{M}$ BAP. Elongation was adequate with $1 \mu \mathrm{M} \mathrm{GA}_{3}$. This protocol for plant regeneration in vitro may be useful in the process of creation and development of new cultivars in a shorter time using apical explants. There is a need to establish efficient rooting and acclimatization for complete in vitro propagation of crambe.

\section{Acknowledgments}

Research supported by Coordenação de Aperfeiçoamento de Pessoal de Nível Superior (CAPES).

\section{References}

Apóstolo NM, Brutti CB, Llorente BE (2005) Leaf anatomy of Cynara scolymus L. in successive micropropagation stages. In Vitro Cell Dev - pl. 41:307-313.

Assis TF, Teixeira SL (1998) Enraizamento de plantas lenhosas. In: Torres AC, Caldas LS, Buso JÁ (eds) Cultura de tecidos e transformação genética de plantas. Brasília: Embrapa-SPI; Embrapa-CNPH. 1:261-296.

Chhikaraa S, Duttaa I, Paulosea B, Jaiwal PK, Dhankher OP (2012) Development of an Agrobacterium-mediated stable transformation method for industrial oilseed crop Crambe abyssinica 'BelAnn'. Ind Crop Prod. 37:457-465.

Dahlke CF, Simonetti APMM (2010) Interferência de diferentes temperaturas na germinação do crambe. Cultivando o Saber, Cascavel. 3(4):167-174.
Falasca SL, Flores N, Lamas MC, Carballo SM, Anschau A (2010) Crambe abyssinica: An almost unknown crop with a promissory future to produce biodiesel in Argentina. Int $\mathbf{J}$ Hydrogen Energ. 35:5808-5812.

Flores R, Nicoloso FT, Maldaner J (2007) Propagação clonal rápida de Pfaffia tuberosa (Spreng.) Hicken utilizando thidiazuron. Rev. Bras. Plantas Med. 9(1):1-7.

Flores R, Nicoloso FT, Maldaner J, Garlet TMB (2009) Benzilaminopurina (BAP) e thidiazuron (TDZ) na propagação in vitro de Pfaffia glomerata (Spreng.) Pedersen. Rev. Bras. Plantas Med. 11(3):292-299.

Gao HB, Wang Y, Gao F, Luo P (1998) Studies on the Plant regeneration from single cell culture of Crambe abysinica. Hereditas. 20:50-52.

Grattapaglia D, Machado MA (1998) Micropropagação. In: Torres AC, Caldas LS, Buso JA (eds) Cultura de tecidos e transformação genética de plantas. Brasília: Embrapa-SPI; Embrapa-CNPH. 1:183-260.

Grimaldi F, Grohskopf MA, Muniz AW, Guidolin AF (2008) Enraizamento in vitro de frutíferas da família Rosaceae. Rev. Ciênc. Agron. 7(2):160-168.

Hartmann HT, Kester DE, Davies FT (1990) Plant propagation: principles and practices (5 ed.) New Jersey. s.n.:647.

Ishigaki G, Gondo T, Suenaga K, Akashi R (2009) Multiple shoot formation, somatic embryogenesis and plant regeneration from seed-derived shoot apical meristems in ruzigrass (Brachiaria ruziziensis). Grassl Sci. 55:46-51.

Jasper SP, Biaggioni MAM, Silva PRA (2010) Comparação do custo de produção do crambe (Crambe abyssinica Hochst) com outras culturas oleaginosas em sistema de plantio direto. Revista Energia na Agricultura, Botucatu. 25(4):141-153.

Kadlec P, Ticha I, Haisel D, Capkova V, Schäfer C (2001) Importance of in vitro pretreatment for ex vitro acclimatization and growth. Plant Sci. 161:695-701.

Khawar KM, Sancak C, Uranbey S, Özcan S (2004) Effect of thidiazuron on shoot regeneration from different explants of lentil (Lens culinaris Medik.) via organogenesis. Turk $\mathbf{J}$ Bot. 28:421-426.

Knights EG (2002) Crambe: A North Dakota case study. A Report for the Rural Industries Research and Development Corporation, RIRDC Publication N. W02/005, Kingston $25 \mathrm{p}$.

Kmec P, Weiss MJ, Milbrath LR, Schatz BG, Hanzel J, Hanson BK, Eriksmoen ED (1998) Growth analysis of crambe. Crop Sci. 38:108-112.

Lara-Fiorezea, ACC, Tomas CA, Fioreze SL, Pilon C, Zanotto MD (2013) Genetic diversity among progenies of Crambe abyssinica Hochst forseed traits Industrial. Crops Prod. 50:771-775.

Leela T, Naresh M, Srikanth RM, Madhusudhan NCh, Cherku PD (2011) Morphological, physico-chemical and micropropagation studies in Jatropha curcas L. and RAPD analysis of the regenerants. Appl Energy. 88:2071-2079.

Li X, Ahlman A, Lindgren H, Zhu LH (2011) Highly efficient in vitro regeneration of the industrial oilseed crop Crambe abyssinica. Ind Crops Prod. 33:170-175.

Li X, Ahlman A, Yan X, Lindgren H, Zhu LH (2010) Genetic transformation of the oilseed crop Crambe abyssinica. Plant Cell Tissue Organ Cult. 100:149-156.

Memon SA, Hou X, Zhu B, Wolukau JN (2009) Highfrequency adventitious shoots regeneration from leaf of non-heading Chinese cabbage (Brassica campestris ssp. chinensis) cultured in vitro. Acta Physiol Plant. 31:11911196. 
Miguel C, Marum L (2011) An epigenetic view of plant cells cultured in vitro: somaclonal variation and beyond. J Exp Bot. 62(11):3713-3725.

Murashige T, Skoog FA (1962) A revised medium for rapid growth and bioassays with Tabaco tissue cultures. Physiol Plantarum. 15(3):473-497.

Neves MB, Trzeciak MB, vinholes PDS, Tillman AC, Villela FA (2007) Qualidade fisiológica de sementes de crambe produzidos em Mato Grosso do Sul. Simpósio Estadual de Agroenergia. 97-98.

Palmer CD, Keller WA (2011) Somatic embryogenesis in Crambe abyssinica Hochst. Ex R.E. Fries using seedling explants. Plant Cell Tissue Organ Cult. 104:91-100.

Pathak H, Dhawan V (2012) ISSR assay for ascertaining genetic fidelity of micropropagated plants of apple rootstock Merton 793. In Vitro Cell Dev - pl. 48:137-143.

Pati PK, Rath SP, Sharma M, Sood A, Ahuja PS (2006) In vitro propagation of rose: a review. Biotechnol Adv. 24:94114.

Paul A, Thapa G, Basu A, Mazumdar P, Kalita MC, Sahoo L (2010) Rapid plant regeneration, analysis of genetic fidelity and essential aromatic oil content of micropropagated plants of Patchouli, Pogostemon cablin (Blanco) Benth. An industrially important aromatic plant. Ind Crop Prod. 32:366-374.

Pavlović S, Adžić S, Cvikić D, Zdravković J, Zdravković M (2012) In vitro culture as a part of Brassica oleracea var. Capitata L. breeding. Genetika. 44(3):611-618.

Purkayastha J, Sugla T, Paul A, Solleti SK, Mazumdar P, Basu A, Mohommad A, Ahmed Z, Sahoo L (2010) Efficient in vitro plant regeneration from shoot apices and gene transfer by particle bombardment in Jatropha curcas. Biol Plantarum. 54(1):13-20.

Purkayastha J, Sugla T, Paul A, Solleti S, Sahoo (2008) Rapid in vitro multiplication and plant regeneration from nodal explants of Andrographis paniculata: a valuable medicinal plant. In Vitro Cell Dev - pl. 43:409-414.

Rocha PSG, Schuch MW, Bianchi VJ, Fachinello JC (2009) Multiplicação e alongamento in vitro do porta-enxerto de Prunus. Biosci. J. 25(1):69-74.

Roscoe R, Richetti A, Maranho E (2007) Análise de viabilidade técnica de oleaginosas para produção de biodiesel em Mato Grosso do Sul. Revista de Política Agrícola. 16:48-59.

Rout GRA, Mohapatra AA, Jain SMB (2006) Tissue culture of ornamental pot plant: A critical review on present scenario and future prospects. Biotechnol Adv. 24:531-560.
Shukla A, Sawhney VK (1991) Comparative regenerative ability of internodal segments of wild type and a genic male sterile line of rapeseed (Brassica napus) cultured in vitro. Plant Sci. 79:95-98.

Silva F, Dea SE, Azevedo CAV (2009) Principal Components Analysis in the Software Assistat-Statistical Attendance. In: World Congress On Computers In Agriculture (eds.) 7, Reno-NV-USA: American Society of Agricultural and Biological Engineers.

Singh SK, Rai MK, Sahoo L (2012) An improved and efficient micropropagation of Eclipta alba through transverse thin cell layer culture and assessment of clonal fidelity using RAPD analysis. Ind Crop Prod. 37:328-333.

Skoog F, Miller CO (1957) Chemical regulation of growth and organ formation in plant tissues cultured in vitro. Sym Soc Exp Biol. 11:118-131.

Sugla T, Purkayastha J, Singh SK, Solleti SK, Sahoo L (2007) Micropropagation of Pongamia pinnata through enhanced axillary branching. In Vitro Cell Dev - pl. 43:409-414.

Taiz L, Zeiger E (2006) Fisiologia vegetal. 3ed. Artmed, Porto Alegre. $722 \mathrm{p}$.

Tibola CT, Radmann EB, Rodrigues AC, Fortes GR, Fachinello JC (2004) Diferentes meios de cultivo no enraizamento in vitro de porta-enxertos de Prunus sp. Revista Brasileira de Agrociência. 10(2):191-19.

Wang YP, Snowdon RJ, Rudloff E, Wehling P, Friedt W, Sonnataq K (2004) Cytogenetic characterization and fae 1 gene variation in progenies from asymmetric somatic hybrids between Brassica napus and Crambe abysinica. Genome. 47:724-731.

Wang YP, Sonntag K, Rudloff E (2003) Development of rapeseed with high erucic acid content by asymmetric somatic hybridization between Brassica napus and Crambe abyssinica. Theor Appl Genet. 106:1147-1155.

Wang YP, Luo P (1998) Intergeneric hybridization between Brassica species and Crambe abyssinica. Euphytica. 101:17.

Zoghlami N, Bouamama B, Khammassi M, Ghorbel A (2012) Genetic stability of long-term micropropagated Opuntia ficus-indica (L.) Mill. plantlets as assessed by molecular tools: Perspectives for in vitro conservation. Ind Crop Prod. 36:59-64.

Zulfigar A, Paulose B, Chhikara S, Dhankher OP (2011) Identifying genes and gene networks involved in chromium metabolism and detoxification in Crambe abyssinica. Environ Pollut. 159:3123-3128. 